\title{
Local Healthcare through Healthy Hearing Program of Special Olympic Korea: Inje Gangwon
}

\author{
Saea Kim¹, Chanbeom Kwak², Woojae Han² \\ 'Department of Speech Pathology and Audiology, Graduate School, Hallym University, Chuncheon, Korea \\ ${ }^{2}$ Division of Speech Pathology and Audiology, Research Institute of Audiology and Speech Pathology, College of Natural Sciences, \\ Hallym University, Chuncheon, Korea
}

\author{
한국스페셜올림픽대회 청각검진을 통해 바라본 지역건강돌봄: 강원도 인제 \\ 김세아 ${ }^{1}$ 곽찬범 ${ }^{2} \cdot$ 한우재 ${ }^{2}$ \\ 한림대학교 일반대학원 언어병리청각학과 ${ }^{1}$ 한림대학교 자연과학대학 언어청각학부 · 청각언어연구소 ${ }^{2}$
}

\begin{abstract}
Intellectual disability is a disability characterized by significant limitations in both intellectual functioning and in adaptive behavior, which covers many everyday social and practical skills. Regardless of those limitations of people with intellectual disabilities, the first International Special Olympics Summer Games were held in July 1968, resulting from various movements for their equality and human right, and their social adaptation. Now, Special Olympics is the world's largest sports organization for children and adults with intellectual disabilities, providing year-round training and competitions to 5.7 million athletes and Unified Sports partners in 172 countries including Korea. In particular, during the Olympic game, health athletes, which offers health screenings to athletes as need in seven areas: Fit Feet (podiatry), FUN fitness (physical therapy), Health Promotion (better health and well-being), Healthy Hearing (audiology), MedFest (sports physical exam), Opening Eyes (vision), and Special Smiles (dentistry). Among them, the Healthy Hearing program includes otoscopy, otoacoustic emission, tympanometry, pure-tone screening, and pure-tone threshold tests, to inform hearing status and additional management for the athletes. This brief communication presents history and principle of Special Olympics including its development in Korea. Also it offers useful information for the athletes participating in the Special Olympics, who have intellectual disability, to understand them, while reporting brief outcomes of healthy hearing program of the Special Olympic Korea held in Inje, Gangwon. In final part of this brief communication, we scrutinize hearing status of people with intellectual disabilities who live in Inje, Gangwon in terms of local healthcare. In closing, we request professional attention and care to them as audiology and speech-language specialists as well as readers of Audiology and Speech Research.
\end{abstract}

Key Words: Healthcare, Healthy hearing, Special Olympic, Intellectual disability, Gangwon.

Received: December 11, 2017 / Revised: January 10, 2018 / Accepted: January 10, 2018

Correspondence: Woojae Han, Division of Speech Pathology and Audiology, College of Natural Sciences, Hallym University, 1 Hallymdaehak-gil, Chuncheon 24252, Korea

Tel: +82-33-248-2216 / Fax: +82-33-256-3420 / E-mail: woojaehan@hallym.ac.kr

\section{INTRODUCTION}

전 세계의 인구 중 약 1 3\%가 지적장애를 가지고 있다. 구체 적으로 가까운 나라인 일본은 2011년 기준으로 741,000여 명 의 지적장애인을 기록하고 있으며(Employment Development Institute Statistics Team, 2016), 장애인 복지제도 및 시설 확충 에서 가장 선진국이라고 일컫는 미국은 지적장애인을 포함한 인 지장애가 2번째로 많이 나타나는 장애로서, 2016년 기준으로 전
체 인구의 약 $4.8 \%$ 를 차지하고 있다(Institute on Disability, 2017). 국내에서는 2016년 기준으로 등록된 지적장애인 수는 195,283 명(남성 117,725명, 여성 77,558명)으로 국내의 전체 등 록 장애인 수의 약 $7.77 \%$ 를 차지하며 5번째로 등록 수가 많은 장애로 추정되고 있다(Ministry of Health and Welfare, 2017). 그러나 세계보건기구의 주목할 만한 분석으로, 전 세계 장애인 들 중 약 $80 \%$ 가 저소득 국가에 있다고 추정되며(World Health Organization, 2011), 지적장애 또한 저소득 국가에서 출현률이 
현저히 높다고 보고되고 있다. 같은 관점으로 국내의 지적장애 인들 중 강원도 거주자를 살펴보면 약 7,896명(남자 4,623명, 여 자 3,273명)이 등록되어 있고(Ministry of Health and Welfare, 2017), 지적장애인들의 장애 특성상 건강관리를 체계적으 로 지원받기가 다소 어려우며 수도권과의 원거리로 인해 강원 지역 거주 지적장애인들은 제한된 의료 지원을 받고 있다.

본 브리프 커뮤니케이션에서는 '한국스페셜올림픽대회 청각 검진을 통해 바라본 지역건강돌봄이라는 주제로 강원도 인제 에 거주하는 지적장애인들의 청각 관리 현황을 이야기해 보고 자 한다. 이를 위해 본 원고에서는 스페셜올림픽의 역사와 기본 철학, 한국스페셜올림픽, 그리고 이러한 대회에 참가하는 발달 장애 및 지적장애의 특성에 대하여 설명하고, 궁극적으로는 강 원도 내에 거주하는 지적장애인들의 건강 및 청각 관리에 대하 여 청각/언어 전문가로서 관심 있게 논의할 것이다.

\section{HISTORY AND PRINCIPLE OF SPECIAL OLYMPICS}

스페셜올림픽(Special Olympic)은 미국 제35대 대통령 John F. Kennedy의 여동생이자 1950 1960년대 미국의 여성 사회 사업가인 Eunice Kennedy Shriver 여사(1921 2009)가, 지적 장애가 있는 사람들이 사회적으로 불공정·불평등하게 대해지 는 것을 알게 된 이후 지적장애인들에 대한 인식을 바꾸고자 노 력한 데서 비롯되었다. 당시 지적장애인들에게는 온전히 놀 공 간조차 사회적으로 허락되지 않는다는 것을 깨닫게 된 Shriver 여사는 스스로 그 공간을 만들고자 노력하였고, 특히 지적장애 를 가진 아동들도 규칙화된 스포츠 활동을 할 수 있다는 걸 알 리고자 그들과 함께하는 여름캠프 등을 기획하였다. 실제로 1962년 Shriver 여사는 지적장애 아동들의 스포츠를 통한 육 체적 활동 참여를 목적으로 집에서 일일 여름캠프를 주최하였 다. 이러한 활동들을 토대로 Shriver 여사는 Joseph P. Kennedy Jr. 재단을 운영하며 본격적인 개척 작업을 시작하였고, 훗날 이는 스페셜올림픽 세계대회의 시초가 되었다(Special Olympics, 2017). 즉, 스페셜올림픽은 지적 혹은 자폐성 장애인 들이 개인이나 단체 스포츠에 참가하여 적절한 지도를 받고 격 려를 받는다면, 그들도 배울 수 있고 즐거움을 느낄 수 있으며 혜택을 누릴 수 있다는 믿음으로 시작되었다. 더불어 스페셜올 림픽은 수많은 장애인들과 비장애인들이 함께 어울림으로써 장애인에 대한 일반인들의 부정적인 시선 및 태도를 개선시켜 줄 수 있으며, 편견 없이 장애인을 온전히 받아들이고 축복해 줄 수 있는 새로운 기회가 반드시 올 것이라는 확고한 신념을 갖고 있다(Special Olympics Korea, 2016a).

국제스페셜올림픽 재단은 Eunice Kennedy Shiver, Frank
Hayden, Robert Cooke, Rafer Johnson, Thomas King, James Lovell, G. Lawrence Rarick이 주축이 되어 1968년 8월 정식 으로 설립되었다. 1968년 미국, 캐나다, 프랑스 3개국이 참가한 첫 스페셜올림픽 세계대회는 미국 시카고에 위치한 Soldier Field에서 개최되었다(Special Olympics, 2017). 이후 스페셜올 림픽의 주관하에 올림픽과 유사한 형식으로 4년마다 하계와 동 계로 구분하며 전 세계를 무대로 세계대회를 개최해 오고 있 다. 일반적으로 하계 대회는 올림픽 개최의 이전 해에, 동계 대 회는 올림픽 개최 후 다음 해에 진행된다. 이 세계대회는 국제 올림픽위원회로부터 ‘올림픽'이라는 용어를 사용하는 것을 허 가받은 유일한 대회이다(Special Olympics, 2017). 현재 스페셜 올림픽은 비영리 스포츠 기구로서 Washington D.C.에 국제본 부를 두고 있으며, 지적 또는 자폐성 장애인들을 위해 지속적인 스포츠 훈련 기회를 제공하고 있다. 또한 전 세계 각 지역에서 수시로 경기대회를 개최하여 선수들의 참여기회를 높임으로써, 지적 및 자폐성 장애인들의 신체적 적응력을 체계적으로 향상 시키고 생산적인 사회 구성원으로 인정받을 수 있도록 기여하 고 있다(Special Olympics Korea, 2016a).

현재까지의 통계적 데이터에 의하면, 스페셜올림픽 세계대회 를 통하여 전 세계 2억 2천만여 명의 지적장애인 선수들이 35 개의 종목에 참여하고 있으며, 370 만여 명의 등록선수들이 세 계 전 지역에서 연 평균 3 만 회 이상의 경기대회에 참가하고 있 다. 선수 이외에도 23 만여 명의 코치들과 60 만여 명의 자원봉 사자들이 스페셜올림픽 위원회에 공식적으로 등록되어 있다. 현재 스페셜올림픽 참여국은 약 180 여 개국이며 위원회 수는 220 개이다. 스페셜올림픽의 각 지역본부는 동아시아 지역, 아프 리카 지역, 아시아-태평양 지역, 유럽-유라시아 지역에 위치해 있고, 한국은 동아시아 지역본부에 속해 있다. 동아시아 지역에 등록된 선수의 수는 $1,315,450$ 명이며, 작년 집계에 비해 그 수가 약 3.4\% 증가하였다(Special Olympics annual census, 2016).

\section{SPECIAL OLYMPICS IN KOREA}

국내에서도 1978년 ‘한국특수올림픽위원회’라는 이름으로 지 적 및 자폐성 장애인들의 신체적 적응력을 향상시키고, 사회 구 성원으로서 그들의 가치를 인정받고자 기구를 설립하였다. 이 후, 1985년 국제스페셜올림픽본부(Special Olympics International)로부터 국가위원회로의 잠정적 승인을 받았고, 2004년 국제본부로부터 정식 인증을 얻었다. 앞서 언급한 대로 현재 스 페셜올림픽코리아(Special Olympics Korea)는 동아시아 지역 본부에 소속되어 왕성한 국내외 활동을 이끌어 오고 있다 (Special Olympics Korea, 2016a).

특히 2013년 평창에서 개최된 동계 스페셜올림픽 세계대회는 
강원 지역은 물론, 국내와 국제 발달장애 선수들을 모두 초청하 였던 세계인의 잔치였다. 이전까지는 스페셜올림픽코리아와 국 제스페셜올림픽은 국내의 일반인들에게는 잘 알려지지 않았으 나, 2013년 평창 동계 세계대회를 계기로 많은 이들의 관심을 얻 게 되었다. 2015년부터 한국스페셜올림픽위원회와 대한지적장 애인스포츠협회가 통합되면서 문화관광부 산하의 체육단체로 자리매김하였다(Special Olympics Korea, 2016a). 현재 스페셜 올림픽코리아 소속의 지적장애인들은 총 24 개의 운동 종목에 참여하고 있으며 수시로 지역 및 학교 시설 단위로 종목별 스 포츠 경기를 진행하고 있다(Special Olympics, 2015).

\section{DEVELOPMENTAL DISABILITY}

발달장애(developmental disability)란 정신 혹은 신체적인 발 달이 생물학적 나이만큼 발달하지 않은 상태를 뜻한다. 일반적 으로 지적장애(intellectual disability), 뇌성마비(cerebral palsy), 유전장애, 염색체장애(down syndrome; 다운증후군, fragile X syndrome), 전반적 발달장애(pervasive developmental disorder) 등으로 분류할 수 있다. 또한 전반적 발달장애는 자폐증, 아스퍼거 증후군, 아동기 붕괴성 장애(childhood disintegrative disorder), 레트 증후군(Rett syndrome)으로 다시 구분된다 (Seoul National University Hospital, 2010a).

발달장애의 원인으로는 다양한 원인들이 복합적으로 작용 하는데, 크게 중추신경계 형성의 이상, 내부 생물학적 환경의 변이, 환경적 요인이 있다. 그중 가장 큰 문제점으로 뇌가 고르 게 발달하지 못하는 것을 들 수 있다. 또한 염색체 이상이나, 미 숙아 등의 생물학적 요인, 임신 중 산모의 음주 및 약물중독 등 의 환경적 요인도 원인이 될 수 있다. 어릴 때 발병하는 경우에 부모는 조금 말을 안 듣는 편이라거나 단순히 다른 아이들과는 다르다는 식으로 생각할 수 있지만, 좀 더 성장하면서 정상 아 동들과의 확연한 차이가 보이게 되면서 인식하게 된다. 이러한 부모의 늦은 인식으로 인해, 조기 진단이 어렵거나 증상이 더 심해지는 경우가 많다. 지적장애를 가진 사람들은 일반적으로 언어 발달이 늦거나, 인지 및 학습 기능에서의 발달 문제를 보 인다. 또한 판단력, 위험 인식, 행동과 감정 조절, 사회관계 등 여 러 어려움을 부차적으로 경험할 수 있다(Seoul National University Hospital, 2010a).

좀 더 구체적으로, 발달장애가 있는 경우 태어난 지 12개월 까지 밤에 잠을 자지 않고, 자주 울며 근력이 떨어지고 감각을 인지하기 어려운 증상을 나타내며, 그 뒤에 만 3세까지는 먹는 음식이 한정되고 새로운 음식에 대한 예민한 반응을 보이는 증 상을 나타낸다(Seoul National University Hospital, 2010a). 또 한 눈의 이상과 사시가 나타날 수 있으며, 걷기 전의 기는 과정
이 없거나 짧은 편이다. 이런 증상뿐 아니라 뇌성마비, 진행성 뇌병변, 뇌기형, 자폐증, 청력 소실, 말초신경 및 신경근 질환, 근 육 질환, 지적장애 등이 나타날 수 있다(Seoul National University Hospital, 2010a). 공통적으로 언어를 이해하고 사용하 는 데 어려움을 겪으며 전반적인 이해와 관계 형성에서 어려움 을 보인다. 또한 어떠한 사물에 특이하게 집착하고, 작은 변화 에도 어려움을 겪는다. 따라서 세세한 증상들에는 웃음을 참 지 못하며 간지럼에 지나치게 반응하고 책 읽기를 힘들어한다. 반복적인 이상적 행동 및 신체적 움직임도 관찰되어, 반복되는 게임 등을 좋아하는 특징이 있다. 반면, 놀이 기구를 못 타고 구 기 종목을 즐기지 못하는 경우도 나타날 수 있다(Seoul National University Hospital, 2010a).

\section{INTELLECTUAL DISABILITY}

국내에서는 지적장애를 3 개의 등급으로 분류하며, 3 개의 등 급 판정 기준은 지능지수(intelligence quotient)와 적응 능력을 토대로 정신건강의학과, 신경과, 또는 재활의학과 전문의들의 정확한 판단에 의해 결정된다. 예를 들어, 웩슬러 지능검사 등 을 이용하여 대상자의 지능지수를 등급으로 판정하며, 이 검사 만으로 판별이 어려울 경우에는 비언어적 지능검사도구를 추가 적으로 시행한다. 만 2세부터 장애 판정을 받을 수 있으며, 성인 이 된 이후 나타난 경우에는 6개월 이상 지속적인 치료 후 장애 가 고착된 시기부터 판정이 가능하다(Ministry of Health and Welfare, 2017).

가장 장애의 정도가 중하다고 판단하는 1 급 판정의 대상자 는 지능지수가 34 이하로, 혼자서 일상생활 유지가 불가능하여 보호자의 도움을 필요로 한다. 지능지수가 35 49일 경우 2급으 로 판정받게 된다. 2 급 대상자는 단순한 행동을 훈련시킬 수 있 으나, 특수한 기술을 요구하는 직업은 수행하기에 한계가 있다. 장애의 정도가 가장 경하다고 판단되는 3 급 대상자는 지능지수 가 50 70 정도이고, 교육을 통하여 사회적 활동이 가능하며 구 체적인 직업 교육을 받는다면 수행 능력을 기를 수 있다(Korean Psychology Association, 2014). 국내에서 1등급 지적장애 인은 50,197명, 2등급은 67,827명, 3등급은 77,259명으로 집계 된다(Ministry of Health and Welfare, 2017).

장애인들의 건강과 활력 있는 생활을 위해 스포츠 활동이 필요하다는 것은 이미 여러 연구를 통하여 검증되었다(Park, 2009). 즉, 스포츠에 참여한 장애인들은 타인과 접촉할 뿐 아니 라 게임을 통해 느끼는 즐거움, 심리적 효과와 주변 사람들과 교류함으로써 사회와 재결합을 촉진시켜 주기에 장애인들에게 스포츠 활동은 곧 사회 통합수단으로써의 긍정적인 효과를 얻 을 수 있다(Park, 2009). 또한 $\operatorname{Kim}(1994)$ 의 연구에 따르면, 스 
포츠 활동은 장애인들에게 기능 회복 및 건강 보호유지뿐 아니 라 신체 기능의 퇴화 예방 차원에서 매우 중요한 재활수단이라 고 기술하였다. 구체적인 예로, 스페셜올림픽에 참여한 지적장 애인 선수들은 비참여자에 비해 사회적-정서적 발달 결과에서 높은 점수를 보여주었고, 사회·정서 발달의 하위 영역인 교사 에 대한 비의존성, 내적 통제, 동료와의 상호작용, 학교에서의 안정감, 성취동기, 호기심 영역에서 비참가자보다 높은 점수를 나타냈다. 결론적으로 종목 간 약간의 차이는 존재하지만, 지 적장애 선수들의 대회 참여 횟수가 많아질수록, 사회 및 정서적 발달에 긍정적인 영향 또한 높아졌다. 이러한 결과들은 스페셜 올림픽 참여는 지적장애인에게 적극 권장되어야 함을 직접적 으로 시사한다(Hong et al., 2009).

\section{HEALTHY ATHLETES PROGRAM}

국제스페셜올림픽에서는 선수들의 건강 향상을 위해 선수건 강증진프로그램(Healthy Athletes Program)을 실시하고 있다. 즉, 스페셜올림픽이 조직화되고 그 규모가 커짐에 따라, 스태프 와 자원봉사자들은 지적장애가 있는 아동 및 성인의 운동선수 들에게 치료받지 않은 건강 문제가 많다는 사실을 인식하게 되 었다. 따라서, 선수건강증진프로그램을 통하여 발달장애 선수 들의 건강 향상뿐 아니라 보조적 치료가 필요한 선수들에게 체 계적인 치료 및 도움을 받을 수 있도록 각 관련 의료진 및 전문 가와 연결하며, 궁극적으로는 발달장애인에 관한 정보를 수집 및 분석하여 그들의 건강한 사회생활의 적응을 증진시키고자 1997년부터 건강한 운동선수(healthy athlete)라는 이니셔티브 (initiative)를 시작으로 도움이 필요한 운동선수들에게 대회 기
간 동안 체계적인 건강검진을 제공하고 있다. 2012년부터는 8 개 국(카자흐스탄, 말라위, 말레이시아, 멕시코, 페루, 루마니아, 남 아프리카 및 태국)과 미국 6개 주에서 스페셜올림픽 건강공동 체 운동이 시작되어 지적장애 선수들의 건강과 복지를 향상시 키고 잠재력을 최대한 발휘할 수 있도록 돕고 있다(Special Olympics Korea, 2016b). 그 결과 선수건강증진프로그램이 시 작된 이래 스페셜올림픽은 지적장애가 있는 사람들을 돕는 세 계 최대 공중보건기관이 되었다. 지금까지 전 세계에서 지적장 애가 있는 사람들 중 190만 명 이상에게 이 프로그램을 통해 건강검진을 실시하였다. 스페셜올림픽 동안 시행되는 선수건강 증진프로그램은 7 개의 검진으로 구성되어 있다. 7 개의 검진은 Opening Eyes, Special Smiles, Healthy Hearing, MedFest, Fit Feet, Fun fitness와 Health Promotion으로, 각각 시각, 구 강, 청각, 내과 및 심장, 발, 신체 기능, 신체 건강을 검사한다.

국내에서도 여러 대회를 통해 매년 선수건강증진프로그램을 진행하고 있으며, 2008년에는 7개의 모든 검진이 처음으로 실시 되었다. 2013년 강원도 평창에서 개최된 평창 동계 스페셜올림 픽 세계대회 기간 동안 약 1,000 여 명의 선수들에게 청각검진을 실시하였고, 그중 200명 이상이 청력 손실로 선별되어 Hear the Word Foundation의 후원으로 보청기 등의 추가적인 의료 지원 을 제공받았다(Special Olympics Korea, 2016b).

\section{HEALTHY HEARING}

선수건강증진프로그램의 7개 검진 영역 중 청각검진은 총 5 개의 검사로 구성되어 있다(Figure 1).

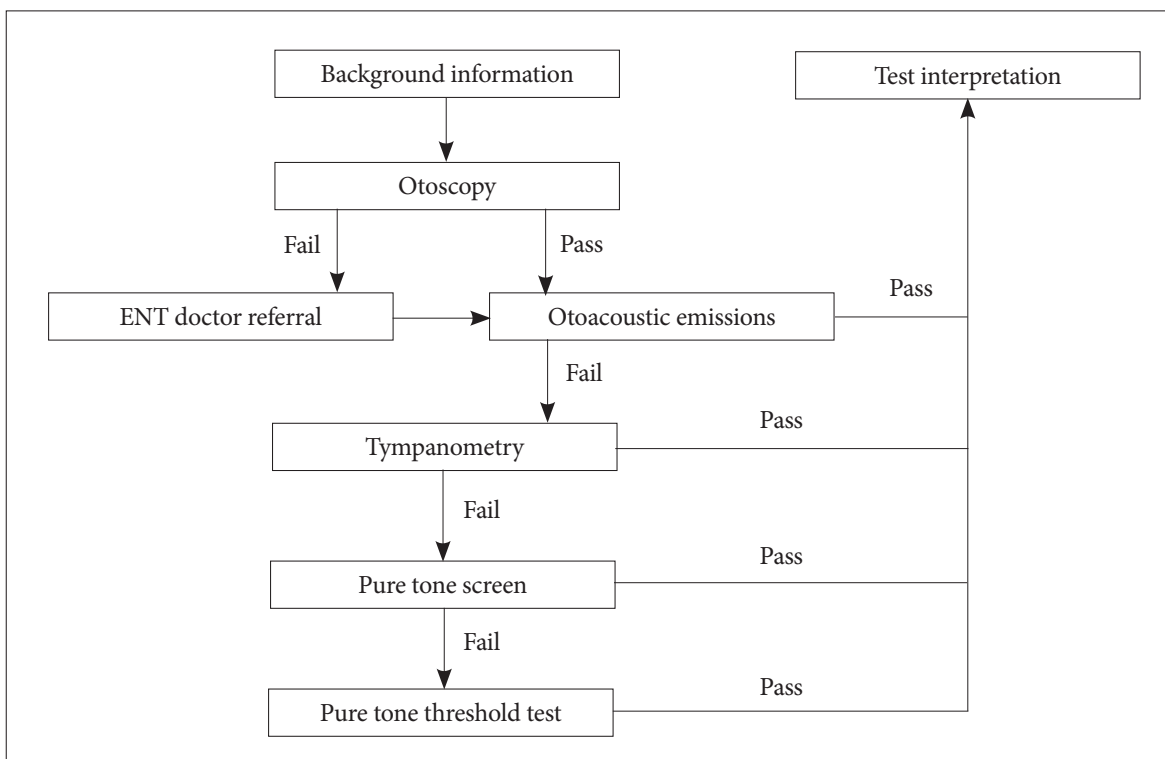

Figure 1. A flow chart of healthy hearing tests in the Special Olympic. 


\section{Background information}

검사를 진행하기 전, 선수의 배경정보를 검사지에 기록한다. 검사지에 기록하는 배경정보로는 성명, 성별, 나이, 소속, 연락 처 등이 있다. 또한 선수 스스로가 느끼는 자신의 청력 상태와 보청기 착용 유무를 문진으로 간단히 확인한다.

\section{Otoscopy examination}

선수의 귀 내부를 확인하기 위해 진행되는 이경검사(otoscopy)를 시작으로 귀에 이물질이 많이 있을 경우, clinical director 중 이비인후과 전문의에게 의뢰하여 이물질을 제거한다. 고 령자 혹은 장애를 가진 사람들은 귀 내부에 있는 귀지 관리를 제대로 하지 못하고 있기 때문에, 연령이 높거나 장애가 심한 선수는 주로 이비인후과 전문의에게 의뢰된다. 검사자는 검사 지에 이물질의 양에 따라 'clear,' "partially blocked', 'blocked"로 표시하며 이물질이 제거된 사람들은 '귀지 제거 후라고 적혀 있는 곳 하단에 'clear', 'partially blocked', 'blocked'로 다시 구 분하여 진료 후의 상태도 기록한다.

\section{Otoacoustic emissions}

이물질 제거와 외이도 상태의 표기 후, 귀에 이어팁을 삽입하 여 이음향방사검사(otoacoustic emissions)를 실시한다. 이음향 방사검사에 대한 지시사항은 "귀에서 소리가 들리시더라도 말 하지 마시고 가만히 있어주세요"로 사용한다. 그러나 귀에 이어 팁을 삽입하는 것을 두려워하는 지적장애선수들도 다수 있기 때문에, 삽입 전 이어팁을 보여주고 아프지 않다는 것을 확실 히 안내하는 것이 바람직하다. 이음향방사검사 시 양이 모두에 서 $\operatorname{pass}^{2}$ 가 나타났을 경우, 추가 검사를 중단한 뒤 검사를 마무 리한다. 만약, 한쪽 귀라도 no pass ${ }^{3}$ 가 되었다면, 고막운동도검 사(tympanometry)를 실시한다.

\section{Tympanogram}

고막운동도검사의 지시사항은 "귀에 압력이 들어가는 검사 입니다. 놀라지 마시고 가만히 있어주세요”를 기반으로 제시하 며, 대상자의 나이가 어리거나 지적장애를 가진 경우, 압력 대 신 '비행기를 탄 기분' 또는 '우우웅-' 소리가 난다고 설명할 것 을 권장한다. 검사 시간을 단축하기 위해 no pass된 귀만 검사

1. 'Clear'는 외이도의 상태가 깨끗한 것을 의미한다. 'Partially blocked' 는 귀지나 이물질이 외이도를 부분적으로 막은 상태이며 'blocked' 는 이경을 통해 고막을 확인할 수 없을 정도로 귀지나 이물질이 외 이도 안을 가득 채운 것을 말한다.

2. 이음향방사검사 시 결과는 'pass' 혹은 'fail'로 구분되며, 'pass'의 경 우 반응이 있는 것으로 확인한다. 고막운동도검사 결과는 $\mathrm{A}$ 형이 나 온 경우를 'pass'라고 표기한다.

3. 이음향방사 검사 시 결과가 'fail'로 나타난 경우와 고막운동도검사 결과에서 $\mathrm{A}$ 형 외의 다른 타입이 나왔을 때 "no pass'라고 기록한다.

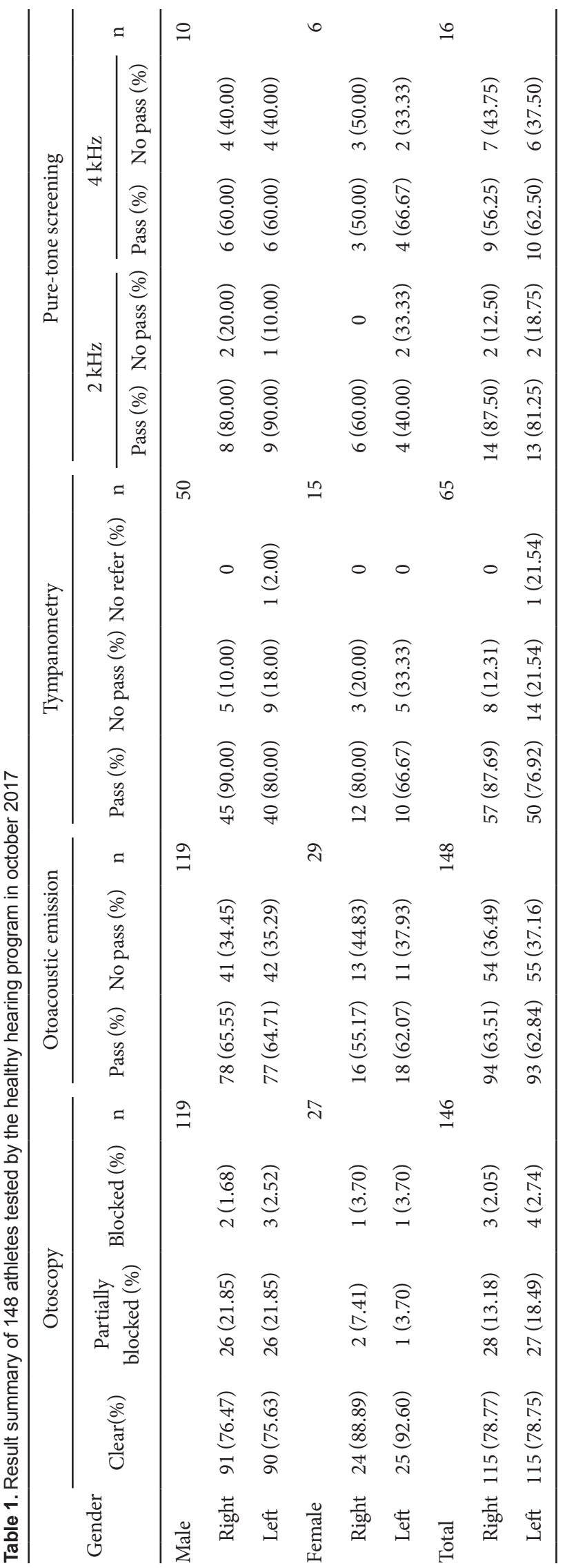


를 시행하며, 결과상 A형이 나타나지 않은 대상자는 순음선별 검사(pure tone screening)를 받게 된다. 고막운동도검사에서 pass가 되었고 대상자의 배경정보에서 스스로 청력에 문제가 없다고 보고하였을 경우 검사 결과 해석으로 진행한다. 그러나 청력 이상이 보고되었다면 정확한 진단을 위해 순음선별검사 를 안내한다.

\section{Pure-tone screening and pure-tone threshold test}

순음선별검사란 $125 \mathrm{~Hz}$ 부터 $8,000 \mathrm{~Hz}$ 까지의 한 옥타브 간 격의 주파수들의 역치를 모두 확인하는 순음청력검사와 달리, $2,000 \mathrm{~Hz}$ 와 4,000 Hz에서 대상자가 $20 \mathrm{~dB} \mathrm{HL}$ 을 듣는지 여부 를 선별하는 검사이다. 스페셜올림픽대회 기간 동안 방음실 설 치 없이 조용한 방에서 순음선별검사 및 순음청력검사를 진행 하기 때문에, 실제로 방음실에서 검사를 받았던 정상 청력인(주 로는 검사자)의 청력역치와 대회 기간 동안 순음검사들을 실시 하는 장소에서의 청력역치를 비교하여 환경적 요소(배경 소음) 로 인해 나타난 청력역치 차이를 고려하였다. 이번 대회기간동 안 검사실에서의 청력역치는 방음실에서의 청력역치보다 높았 으며 그 값은 $2 \mathrm{kHz}$ 와 $4 \mathrm{kHz}$ 에서 각각 $5 \mathrm{~dB}$ 이었다. 선수건강 증진프로그램에서는 이러한 환경적 요인을 배제하기 위해 모든
대상자의 순음청력검사 역치 결과에서 $2 \mathrm{kHz}$ 와 $4 \mathrm{kHz}$ 에서의 역치에 $5 \mathrm{~dB}$ 을 빼서 결과를 산정하였다. 이 검사는 5-dB step으 로 진행되었으며, 충분히 큰 소리를 제시한 뒤 $5-\mathrm{dB}$ 간격으로 검사음을 점차 하강시켜 $20 \mathrm{~dB}$ HL에서 듣는지 여부를 확인한 다. 이때 순음선별검사에서 no pass가 되었다면, 해당선수의 좀 더 정확한 역치 확인을 위해 순음역치검사(pure-tone threshold test)를 실시하였다.

Table 1은 2017년 10월 강원도 인제에서 실시된 제33회 선수 건강증진프로그램의 청각검진 결과를 정리한 것이다. 청각검진 에 참여한 선수들은 총 148 명이었다. 이 중 이경검사를 받은 선 수는 146 명(2명은 본인 거부로 이경검사 미실시)이었으며 이음 향방사검사를 받은 선수는 148 명이었다. 이음향방사검사를 실 시한 사람들 중 몇몇은 주변 상황의 소음, 약물 치료, 내적 artifact로 인해 검사 결과의 신뢰도가 낮았다. 따라서 이들은 no pass로 기록하여 추가 검사를 진행하였다. 귀지 제거 및 이어팁 삽입을 거부하여 검사를 진행하지 못한 선수들도 있었다. 결과 적으로, 이음향방사검사를 통과한 83명은 더 이상의 검사를 받 지 않았으며 통과하지 못한 65 명에게는 고막운동도검사를 진 행하였다. 고막운동도 검사 시, A형이 나오지 않은 선수들은 49 명이었고, 이들은 약물치료 또는 다른 여러 가지 이유로 Ad형,
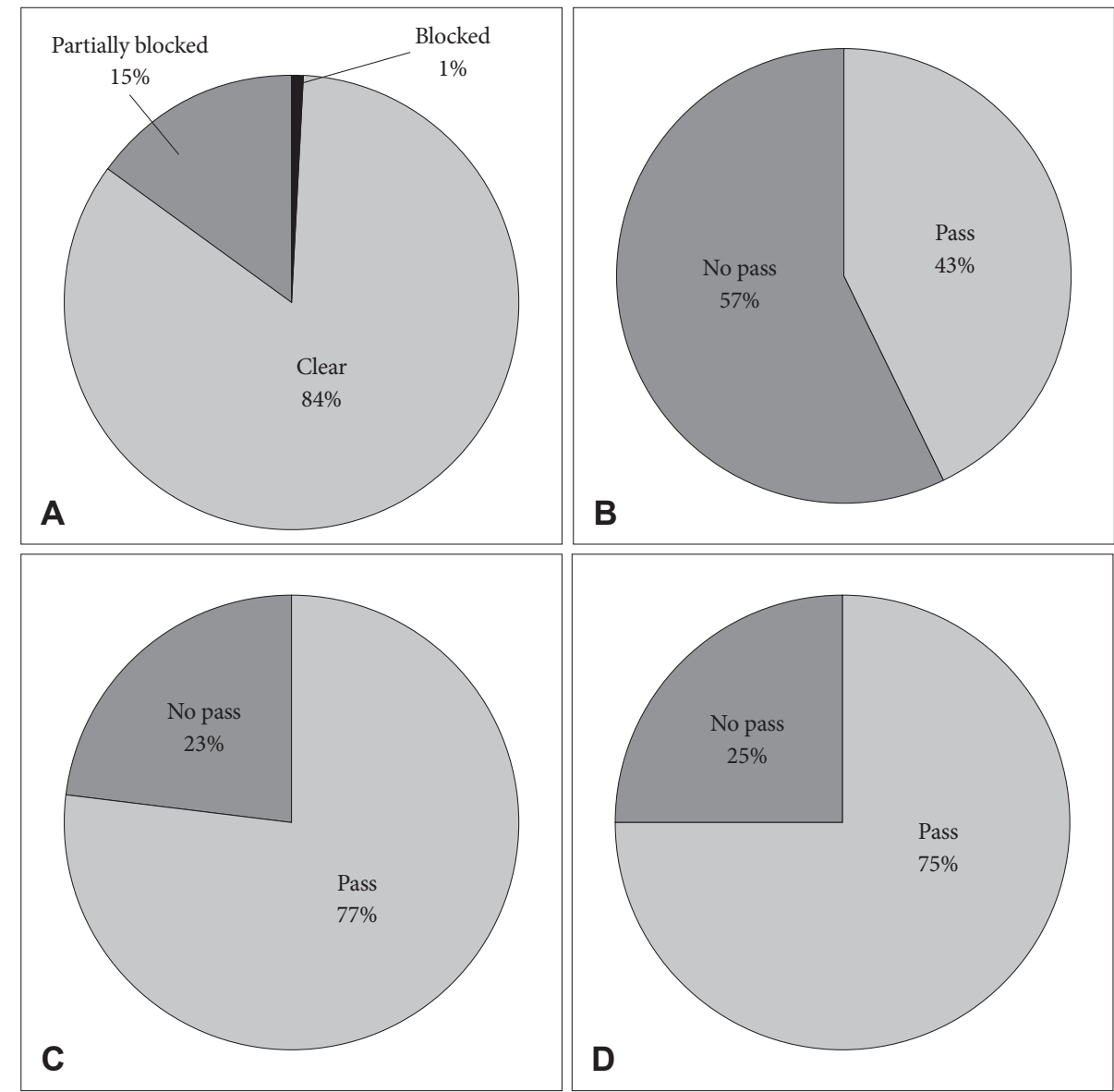

Figure 2. Thirty-six Inje residents who have intellectual disability conducted by the healthy hearing program during the Special Olympic Unified Sports. Four panels were results of otoscopy (A), otoacoustic emission (B), tympanometry (C), and pure-tone screening (D). 
B형, As형의 비정상적 결과가 나타났다. 따라서, 순음선별검사 는 16 명이 실시하였으며, 최종적으로 순음역치검사까지 진행한 선수들은 3 명이었다. 순음역치검사를 받은 3 명에게는 가까운 난청센터나 이비인후과를 방문하여 보다 정밀한 청력검사를 받 도록 권장하였다.

\section{CONCLUSIONS}

한국은 눈부신 경제성장을 통하여 $\mathrm{OECD}$ 회원 국가로서 당 당히 선진국 대열에 들어섰다. 특히 보건의료 분야의 시설 및 전문 인력의 확보는 세계 최고 수준을 나타내고 있으며, 해마다 수많은 국외 환자들이 국내의 의료 시설을 이용하고 있다. 그러 나 이러한 우수한 보건의료 시설 및 인력 기반의 확충은 수도권 및 대도시에서만 국한될 뿐, 상대적으로 수도권으로부터 거리 가 먼 강원도 내의 소도시들에서는 보건의료 및 사회복지 서비 스 제공 기반이 매우 열악하다. 강원도는 지역의 특성상 읍, 면, 리의 소단위로 갈수록 지역 주민들이 받을 수 있는 건강 관련 서비스는 제한적이며 특히 청각 관리는 사각지대이다. 게다가 지적장애인과 같이 본인의 의사를 정확하게 표현하는 데 한계 가 있다면 청각 관리의 혜택을 받는 것은 더욱 어렵다.

Figure 2는 2017년 10월 강원도 인제에서 실시된 제33회 선 수건강증진프로그램 중 청각검진을 받은 인제군의 장애인복지 관 소속 지적장애인들의 검사 결과이다. 비록 프로그램 실시 당 일의 참여 인원은 총 36 명(남성 25 명, 여성 11 명)으로 매우 적은 수이기에 검사 결과가 인제군 지적장애인들의 청각 관리의 현 실태라고 단정 지을 수는 없지만, 실시한 4 개의 검사 결과들이 보여주는 수치는 간과하기가 어렵다. 예를 들어, 이경검사는 36 명 중 35 명이 참여하여 70 귀(35명의 양이) 중 11 귀(16\%)가 부분 적으로 혹은 완전히 귀지로 막혀서 외부 소리를 원활히 듣는 데 한계가 있었다(Figure 2A). 가장 부정적인 결과를 보인 이음 향방사검사는, 36명(72귀) 중 57\%(41귀)가 no pass를 기록하여 검사를 받은 지적장애인들 중 절반 이상이 정상 결과를 나타내 지 못하였다. 또한 고막운동도검사와 순음선별검사에서 각각 $23 \%(11$ 귀), 25\%(2귀)가 정상 결과의 범주를 벗어났다. 물론, 스 페셜올림픽대회 기간 동안 진행된 간이검사실의 소음 상태와 청각검사 기기의 노후 등도 본 검사 결과에 부정적인 영향을 미쳤을 가능성을 배제할 수는 없으나, Figure 2에서 보여지는 강원도 인제군의 지적장애인, 더 나아가 지역 주민들의 청각 관 리는 다소 걱정스런 메시지를 전해주고 있다.

최근 들어 많은 지역사회 단위에서 맞춤형 건강증진서비스 를 제공할 수 있는 인력 양성 및 시설 확충에 힘을 쏟고 있다. 신문기사를 통해서 사회복지 분야에서도 방문요양, 돌봄종합서 비스 등의 중심단어를 낯설지 않게 접할 수 있다. 우리 청각 분
야에서도 이제는 원활히 청각 관리를 받기 어려운 지역 주민들 혹은 보건·복지의 사각지대에 속한 중복 장애인들을 위해 직 접 찾아가는 지역건강돌봄 서비스가 절실히 필요한 때이다.

중심 단어 : 건강돌봄·청각관리·스페셜올림픽·지적장애·강원.

Acknowledgments

이 논문은 2015년 대한민국 교육부와 한국연구재단의 지원을 받 아 수행된 연구입니다(NRF-2015S1A3A2046760).

\section{REFERENCES}

Employment Development Institute Statistics Team. (2016, August 31). 2016 Disability Statistics at a Glance. Korea Employment Agency for the Disabled. Retrieved from https://www.kead.or.kr/common/comm_board_ v.jsp?no=377\&main=4\&sub1 $=4 \&$ sub2 $=0$.

Hong, Y. J., Park, J. H., \& Kang, S. Y. (2009). The effect of special olympics participation level on the social and emotional development of people with intellectual disability. Journal of Korean Physical Education Association for Girls and Women, 23(1), 17-26.

Institute on Disability. (2017, February 14). 2016 Disability Statistics Annual Report. Annual Disability Statistics Compendium. Retrieved from https://disabilitycompendium.org/.

Kim, S. J. (1994). A study on the relationship between experience of sport participation and sport attitude in physically handicapped (unpublished master's thesis). Ewha University, Seoul.

Korean Psychological Association. (2014, April). Intellectual Disability. Korean Psychological Association. Retrieved from http:// www.koreanpsychology.or.kr/psychology/glossary.asp.

Lee, S. Y. (1985). Significance of Sports for the Disabled. Paralympic quarterly paper, Spring.

Ministry of Health and Welfare. (2017, April 13). Criteria for disability grade. Ministry of Health and Welfare. Retrieved from http://www.law. go.kr/\%ED\%96\%89\%EC\%A0\%95\%EA\%B7\%9C\%EC\%B9\%99/\%EC\% 9E\%A5\%ЕC\%95\%A0\%ЕB\%93\%B1\%ЕA\%B8\%89\%ED\%8C\%90\%ЕC\% A0\%95\%ЕA\%B8\%B0\%EC\%A4\%80.

Park, J. H. (2009). The Effect of Special Olympics Participation on the Social and Emotional Development of People with Intellectual Disability (unpublished master's thesis). Ewha University, Seoul.

Seoul National University Hospital. (2010a, August 8). Developmental Disability. Seoul National University Hospital. Retrieved from http://www. snuh.org/health/nMedInfo/nView.do? category=DIS\&medid=AA00 0618.

Seoul National University Hospital. (2010b, August 10). Intellectual Disability. Seoul National University Hospital. Retrieved from http://www.snuh. org/health/nMedInfo/nView.do?category=DIS\&medid=AA000770.

Special Olympics. (2015, October 11). Korea Fact Sheet. Special Olympics. Retrieved from https://media.specialolympics.org/resources/reports/ country-profiles/KoreaFactSheet.pdf.

Special Olympics. (2017, March 5). Our History. Special Olympics. Retrieved from https://www.specialolympics.org/Sections/What_We_Do/Our_ History.aspx.

Special Olympics Annual Census. (2016, December 6). 2016 Research Report. Special Olympics. Retrieved from http://annualreport.specialolympics.org/reach-report.

Special Olympics Korea. (2016a, April 11). Group Introduction. Special Olympics Korea. Retrieved from http://sokorea.or.kr/index.php?tpf= intro/sok.

Special Olympics Korea. (2016b, April 30). Health Program. Local Healthcare. Special Olympics Korea. Retrieved from http://sokorea.or.kr/index. php?tpf= health/health_program.

World Health Organization. (2011, September 8). World Report on Disability. (pp. 262). Geneva: World Health Organization. 